\title{
Cutting the Knot of the World Problem: Sri Aurobindo's Experiential and Philosophical Critique of Advaita Vedānta
}

\author{
Swami Medhananda
}

check for updates

Citation: Medhananda, Swami. 2021 Cutting the Knot of the World Problem: Sri Aurobindo's Experiential and Philosophical Critique of Advaita Vedānta. Religions 12: 765. https://doi.org/ 10.3390/rel12090765

Academic Editor: Trichur S. Rukman

Received: 23 August 2021

Accepted: 8 September 2021

Published: 14 September 2021

Publisher's Note: MDPI stays neutral with regard to jurisdictional claims in published maps and institutional affiliations.

Copyright: (C) 2021 by the author. Licensee MDPI, Basel, Switzerland. This article is an open access article distributed under the terms and conditions of the Creative Commons Attribution (CC BY) license (https:/ / creativecommons.org/licenses/by/ $4.0 /)$.
Ramakrishna Institute of Moral and Spiritual Education, Mysore 570020, India; sw.medhananda@gmail.com

\begin{abstract}
This article proposes to examine in detail Aurobindo's searching — and often quite originalcriticisms of Advaita Vedānta, which have not yet received the sustained scholarly attention they deserve. After discussing his early spiritual experiences and the formative influence of Sri Ramakrishna and Swami Vivekananda on his thought, I outline Aurobindo's philosophy of "realistic Adwaita". According to Aurobindo, the sole reality is the Divine Saccidānanda, which is not only the static impersonal Brahman but also the personal, dynamic Cit-Śakti (Consciousness-Force), which manifests as everything in this universe. At various points in his corpus, Aurobindo criticizes Advaita Vedānta on three fronts. From the standpoint of spiritual experience, Aurobindo argues that Śankara's philosophy is based on a genuine, but partial, experience of the Infinite Divine Reality: namely, the experience of the impersonal nondual Absolute and the corresponding conviction of the unreality of everything else. Aurobindo claims, on the basis of his own spiritual experiences, that there is a further stage of spiritual experience, when one realizes that the impersonal-personal Divine Reality manifests as everything in the universe. From a philosophical standpoint, Aurobindo questions the logical tenability of key Advaitic doctrines, including $m \bar{a} y \bar{a}$, the exclusively impersonal nature of Brahman, and the metaphysics of an illusory bondage and liberation. Finally, from a scriptural standpoint, Aurobindo argues that the ancient Vedic hymns, the Upanișads, and the Bhagavad-Gitta , propound an all-encompassing Advaita philosophy rather than the world-denying Advaita philosophy Śankara claims to find in them. This article focuses on Aurobindo's experiential and philosophical critiques of Advaita Vedānta, as I have already discussed his new interpretations of the Vedāntic scriptures in detail elsewhere. The article's final section explores the implications of Aurobindo's life-affirming Advaitic philosophy for our current ecological crisis.
\end{abstract}

Keywords: Sri Aurobindo; Advaita Vedānta; māyā; spiritual experience; Sri Ramakrishna

The theory of Illusion cuts the knot of the world problem, it does not disentangle it; it is an escape, not a solution: a flight of the spirit is not a sufficient victory for the being embodied in this world of the becoming...

—Sri Aurobindo, The Life Divine (CWSA 21-22, p. 485)

Over a millennium ago, Gauḍapāda and Śañkarācārya attempted to prove that the Vedāntic scriptures taught a distinctive Advaita philosophy, according to which the sole reality is the impersonal (nirguna) nondual Brahman and everything else- - the personal God, individual souls, and the world-is ultimately nonexistent. ${ }^{1}$ Among the various schools of Vedānta, Śankkara's Advaita Vedānta remains by far the most widely known and studied school of Vedānta, both within and outside of India. Indeed, when many people hear the word "Advaita", they immediately think of Śankara's Advaita Vedānta.

In fact, however, there are numerous subtly different kinds of Advaita philosophy in the Indian tradition. Tantric philosophies, including Śāktism and Kashmir Shaivism, uphold a world-affirming nondualism, according to which the ultimate reality Paramaśivawhich is at once personal and impersonal, static and dynamic-actually manifests as everything and everyone in the universe. According to the Kashmir Shaiva philosopher Abhinavagupta, Sankara and his followers made the great mistake of failing to grant 
ultimate reality to Śakti, thereby depriving Brahman of the power to manifest as the world, in effect reducing Brahman to the status of an insentient entity "like a jar" (Singh 1985, p. 21). Rāmānuja's Viśiștadvaita Vedānta is a "qualified" form of Advaita philosophy, which holds that the ultimate reality is the personal God Viṣnu-Nārāyana, whose "body" (śarìra) consists of all sentient individual souls (cit) and the entire world of insentient entities (acit). Toward the beginning of his commentary on the Brahmasütra, Rāmānuja presented a lengthy sevenfold refutation of Śankara's Advaita Vedānta (saptavidhā-anupapatti), arguing, for instance, that neither Brahman nor the individual soul can be the locus of ignorance (avidy $\bar{a}$ ), and that the Advaitic doctrines of avidy $\bar{a} / m \bar{a} y \bar{a}$, inexplicability (anirvacanīyat $\bar{a}$ ), and jīvanmukti (liberation while living) are untenable (Grimes 1990). Vallabha's Śuddhādvaita Vedānta, meanwhile, presented itself as a "pure" (śuddha) form of nondualism, in polemical opposition to Śankara's Advaita philosophy, which, according to Vallabha and his followers, compromised its own nondual position by positing māy $\bar{a}$ as a second entity alongside Brahman.

More recently, the Indian philosopher-mystic Sri Aurobindo (1872-1950) has championed a "realistic Adwaita" philosophy, which he explicitly contrasts with Śankara's "illusionistic" form of Advaita (CWSA 29, p. 393). This article proposes to examine in detail Aurobindo's searching, and often quite original, criticisms of Śankara's Advaita Vedānta, which have not yet received the sustained scholarly attention they deserve. To appreciate the nuances of his criticisms, we first need some understanding of his early intellectual and spiritual development and the basic tenets of his own spiritual philosophy. To this end, Section 1 discusses Aurobindo's early spiritual experiences and the formative influence of Sri Ramakrishna and Swami Vivekananda on his thought. Section 2 outlines Aurobindo's philosophy of "realistic" Advaita. According to Aurobindo, the sole reality is the Divine Saccidānanda, which is not only the static impersonal Brahman but also the personal, dynamic Cit-Śakti (Consciousness-Force), which manifests as everything in this universe.

With this background in place, the remainder of the article focuses on Aurobindo's criticisms of Advaita Vedānta. At various points in his corpus, Aurobindo criticizes Śankara's Advaita Vedānta on three fronts. From a scriptural standpoint, Aurobindo argues that the ancient Vedic hymns, the Upanișads, and the Bhagavad-Gitta, propound an all-encompassing Advaita philosophy rather than the world-denying Advaita philosophy Śankara claims to find in them. Since I have discussed Aurobindo's scriptural interpretations in detail elsewhere (Maharaj 2015, 2020a; Medhananda 2021), I will only briefly discuss them here at the end of Section 1. From the standpoint of spiritual experience, Aurobindo argues that Śankara's philosophy is based on a genuine, but partial, experience of the Infinite Divine Reality: namely, the experience of the impersonal nondual Absolute and the corresponding conviction of the unreality of everything else. Aurobindo claims, on the basis of his own spiritual experiences, that there is a further stage of spiritual experience, when one realizes that the impersonal-personal Divine Reality manifests as everything in the universe. I discuss his experiential critique of Advaita Vedānta in Section 3. Finally, from a philosophical standpoint, Aurobindo questions the logical tenability of key Advaitic doctrines, including $m \bar{a} y \bar{a}$, the exclusively impersonal nature of Brahman, and the metaphysics of an illusory bondage and liberation. I discuss his philosophical criticisms of Advaita Vedānta in Section 4. In Section 5, I conclude the article by exploring the contemporary ecological implications of Aurobindo's criticisms of Advaitic illusionism and his own life-affirming Integral Advaitic philosophy.

\section{Aurobindo's Formative Training, Spiritual Experiences, and Scriptural Commentaries}

After studying classics at Cambridge University, Aurobindo returned to India in 1893, where he deepened his knowledge of Bengali and Sanskrit, became an active participant in the independence movement, and started practicing Yoga. During this formative time, he was strongly influenced by the life and teachings of the Bengali saint Sri Ramakrishna (18361886) and his chief disciple Swami Vivekananda (1863-1902). In his essay “Spirituality and 
Nationalism" (1908), Aurobindo affirmed that Ramakrishna was the "last and greatest" of all the avatāras, "for while others felt God in a single or limited aspect, he felt Him in His illimitable unity as the sum of an illimitable variety" (CWSA 6-7, p. 979). Indeed, Aurobindo claimed that between 1908 and 1912, he received three messages on a mystical plane from Ramakrishna, who had of course passed away decades earlier (CWSA 10-11, p. 128). In a 1913 letter, Aurobindo wrote to a disciple: "Remember also that we derive from Ramakrishna. For myself it was Ramakrishna who personally came and first turned me to this Yoga" (CWSA 36, p. 179).

Aurobindo seemed to have been especially impressed by Ramakrishna's teachings on God and the different stages of spiritual experience. Ramakrishna frequently taught that "Brahman and Śakti are inseparable" (brahma o śakti abhed)—that is, the impersonal nondual Brahman and the personal, dynamic Śakti are equally real aspects of one and the same Infinite Divine Reality (Gupta [1942] 1992, p. 550; Gupta [1897] 2010, p. 568). Moreover, Ramakrishna often distinguished two stages of spiritual realization which he called "jñ̄nna" and "vijñ̄ana":

The jñann̄ gives up his identification with worldly things, discriminating, "Not this, not this". Only then can he realize Brahman. It is like reaching the roof of a house by leaving the steps behind, one by one. But the vijñanni, who is more intimately acquainted with Brahman, realizes something more. He realizes that the steps are made of the same materials as the roof: bricks, lime, and brick-dust. That which is realized as Brahman through the eliminating process of "Not this, not this" is then found to have become the universe and all its living beings. The vijūann $\bar{\imath}$ sees that the Reality which is impersonal [nirguna] is also personal [saguna]. A man cannot live on the roof for a long time. He comes down again. Those who realize Brahman in samādhi come down also and find that it is Brahman that has become the universe and its living beings ... This is known as vijñanna. (Gupta [1942] 1992, pp. 103-4; Gupta [1897] 2010, pp. 50-51)

According to Ramakrishna, the jĩññ̄, a follower of Śankara's Advaita Vedānta, realizes that nirguna Brahman alone is real and that the world is unreal, a mere "framework of illusion" (Gupta [1942] 1992, p. 478; Gupta [1897] 2010, p. 479). By contrast, the vijñannī, such as Sri Ramakrishna himself, first attains the Advaitic realization of nirguna Brahman in nirvikalpa samādhi but then goes on to attain the even greater and more expansive realization that the Infinite Divine Reality is not only nirguna Brahman but also Sakti, the personal God who has become everything in the world. Hence, the vijñann $\bar{\imath}$ sees this world not as unreal but as a "mansion of mirth", a real manifestation of Śakti (Gupta [1942] 1992, p. 478; Gupta [1897] 2010, p. 479). In contrast to Śankara, Ramakrishna championed a world-affirming Advaita philosophy, according to which the sole reality is the impersonalpersonal Infinite Reality which is both immanent in the universe and beyond it.

Remarkably, between 1908 and 1909, Aurobindo seemed to have had spiritual experiences that correspond quite closely to what Ramakrishna called "jñanna" and "vijñ̄ana". In January 1908, Aurobindo met in Baroda a Yogi named Vishnu Bhaskar Lele who instructed him in meditation. Aurobindo reported that after three days of training under Lele, he had a "series of tremendously powerful experiences", which made him "see with a stupendous intensity the world as a cinematographic play of vacant forms in the impersonal universality of the Absolute Brahman" (CWSA 35, pp. 239-40). Aurobindo later clarified that these experiences were Advaitic in nature: they revealed to him the nondual reality of the impersonal Ātman and the corresponding unreality of the universe (CWSA 35, p. 239).

In May 1908, Aurobindo was incarcerated for a year in the Alipore jail for his political activities. Aurobindo claimed to have received instructions in meditation from Vivekananda on an occult plane in his jail cell in Alipore: "Vivekananda in the Alipore jail gave me the foundations of that knowledge which is the basis of our Sadhana [spiritual practice]" (CWSA 36, p. 179). During his imprisonment, Aurobindo also practiced in earnest "the Sadhana of the Gita", which led him, in his own words, to "realise what Sri Krishna demanded of Arjuna and what He demands of those who aspire to do His 
work, to be free from repulsion and desire, to do work for Him without the demand for fruit, to renounce self-will and become a passive and faithful instrument in His hands ..." (CWSA 8, p. 5). His intense practice of the teachings of the Gitta in the Alipore jail culminated in what he describes as a transformative mystical experience:

I looked at the jail that secluded me from men and it was no longer by its high walls that I was imprisoned; no, it was Vasudeva [another name for Kṛnna] who surrounded me. I walked under the branches of the tree in front of my cell but it was not the tree, I knew it was Vasudeva, it was Sri Krishna whom I saw standing there and holding over me his shade. I looked at the bars of my cell, the very grating that did duty for a door and again I saw Vasudeva. It was Narayana who was guarding and standing sentry over me. Or I lay on the coarse blankets that were given me for a couch and felt the arms of Sri Krishna around me, the arms of my Friend and Lover. This was the first use of the deeper vision He gave me. I looked at the prisoners in the jail, the thieves, the murderers, the swindlers, and as I looked at them I saw Vasudeva, it was Narayana whom I found in these darkened souls and misused bodies. (CWSA 8, pp. 6-7)

Notice the striking similarity between Aurobindo's Alipore experience and what Ramakrishna calls "vijñ̄ana". According to Ramakrishna, the vijūann̄ first attains knowledge of the impersonal Atman and then achieves the deeper insight that the supreme impersonal-personal God "has become the universe". Like Ramakrishna's vijñanni, Aurobindo reportedly had the Advaitic experience of the impersonal Ätman under Lele and then, a year later in the Alipore jail, had the mystical experience of Lord Kṛ̣na pervading the entire universe.

Aurobindo's transformative spiritual experiences, as well as his acquaintance with the life and teachings of Ramakrishna and Vivekananda, led him to champion a new, life-affirming interpretation of the Vedic hymns, Upanișads and Gìta, in explicit opposition to Śankkara's illusionistic approach. Accordingly, in his early essay "Karmayoga" (1909), he explicitly rejected Śankara's illusionistic interpretation of the Vedāntic scriptures in favor of a life-affirming and harmonizing approach suggested to him by Ramakrishna and Vivekananda:

[T]he word Vedanta is usually identified with the strict Monism and the peculiar theory of Maya established by the lofty and ascetic intellect of Shankara. But it is the Upanishads themselves and not Shankara's writings, the text and not the commentary, that are the authoritative Scripture of the Vedantin. Shankara's, great and temporarily satisfying as it was, is still only one synthesis and interpretation of the Upanishads. There have been others in the past which have powerfully influenced the national mind and there is no reason why there should not be a yet more perfect synthesis in the future. It is such a synthesis, embracing all life and action in its scope, that the teachings of Sri Ramakrishna and Vivekananda have been preparing. (CWSA 13, pp. 10-11)

In the next few years, Aurobindo went on to write full-scale commentaries on the Vedic hymns (CWSA 15), the Bhagavad-Gìta (CWSA 19), and the Ísa (CWSA 17, pp. 1-91) and Kena Upanișads (CWSA 18). For instance, in Essays on the Gita, he argues-against Śankara and other traditional commentators-that the Gìt $\bar{a}$ conceives God as the impersonal-personal "Purusottama" who manifests as everything in the universe and teaches that karmayoga, bhaktiyoga, and jūannayoga are equally capable of leading to salvific knowledge of God (Maharaj 2015).

\section{Aurobindo's Philosophy of "Realistic Adwaita"}

According to Aurobindo, the sole reality is Saccidānanda (Being/ConsciousnessForce/Bliss), the infinite, impersonal-personal Divine Consciousness which, in its personal and dynamic aspect as Śakti, manifests as everything in the universe. In his philosophical magnum opus The Life Divine (1940; CWSA 21-22), he elaborates this all-inclusive Advaita 
philosophy in great detail. In an illuminating letter, he summarizes the core argument of The Life Divine as follows:

There is possible a realistic as well as an illusionist Adwaita. The philosophy of The Life Divine is such a realistic Adwaita. The world is a manifestation of the Real and therefore is itself real. The reality is the infinite and eternal Divine, infinite and eternal Being, Consciousness-Force and Bliss [i.e., Saccidānanda]. This Divine by his power has created the world or rather manifested it in his own infinite Being. But here in the material world or at its basis he has hidden himself in what seem to be his opposites, Non-Being, Inconscience and Insentience ... The Being which is hidden in what seems to be an inconscient void emerges in the world first in Matter, then in Life, then in Mind and finally as the Spirit. The apparently inconscient Energy which creates is in fact the ConsciousnessForce of the Divine and its aspect of consciousness, secret in Matter, begins to emerge in Life, finds something more of itself in Mind and finds its true self in a spiritual consciousness and finally a supramental consciousness through which we become aware of the Reality, enter into it and unite ourselves with it. This is what we call evolution which is an evolution of consciousness and an evolution of the Spirit in things and only outwardly an evolution of species. (CWSA 29, p. 393)

According to Aurobindo's understanding of Śankara's "illusionist Advaita" philosophy, the sole reality is the impersonal and attributeless (nirguna) Pure Consciousness, which only appears to manifest as this world due to our ignorance. By contrast, according to Aurobindo's "realistic" Advaita, the Divine Saccidānanda is both personal (saguna) and impersonal (nirguna): the Sat aspect of Saccidānanda corresponds to the impersonal Absolute accepted by Śankara, while the Cit aspect of Saccidānanda is "Consciousness-Force", a personal and dynamic "Cit-Śakti", which has the inherent capacity to manifest in and as the world (CWSA 21-22, p. 201). Hence, Aurobindo, unlike Śankara, holds that everything in the world is an emphatically real manifestation of Divine Consciousness.

According to Aurobindo, evolution has both an outer and an inner dimension. Darwin's theory of physical evolution through natural selection provides a more or less accurate account of how various species have evolved in the course of the earth's history. However, what Darwin overlooked is the inner spiritual evolution of consciousness through the mechanism not of natural selection but of divine "involution". Divine Consciousness, Aurobindo claims, is "involved" in everything in the universe and progressively manifests itself at each stage of the evolutionary process from matter to life to mind, and, ultimately, to Supermind. Up to this point, he claims, humanity has evolved to the stage of mind, which is only a transitional stage on the way to the culminating stage of Supermind, upon reaching which we will realize that we are none other than the one infinite Divine Consciousness playfully manifesting as everything in the universe. Moreover, he argues that the evolutionary transition from mind to Supermind is inevitable, since the Divine Consciousness involved in the human mind will necessarily press forward until it can manifest itself here on earth to the fullest extent. ${ }^{2}$ Through the practice of Aurobindo's Yoga, we can facilitate and accelerate the "descent" of the "supramental Truth-Consciousness" by allowing ourselves to be transformed by the Divine at all levels of our being (CWSA 36, p. 548).

\section{Aurobindo's Experiential Critique of Advaita Vedānta}

One of Aurobindo's most important and original criticisms of Advaita Vedānta is that its metaphysics is based on a genuine, but nonetheless incomplete and partial, spiritual experience. He makes this criticism especially forcefully in the following passage from a letter: ${ }^{3}$

The Shankara knowledge is ... only one side of the Truth; it is the knowledge of the Supreme as realised by the spiritual Mind through the static silence of the pure Existence. It was because he went by this side only that Shankara was unable 
to accept or explain the origin of the universe except as illusion, a creation of Maya. Unless one realises the Supreme on the dynamic as well as the static side, one cannot experience the true origin of things and the equal reality of the active Brahman. The Shakti or Power of the Eternal becomes then a power of illusion only and the world becomes incomprehensible, a mystery of cosmic madness, an eternal delirium of the Eternal. Whatever verbal or ideative logic one may bring to support it, this way of seeing the universe explains nothing; it only erects a mental formula of the inexplicable. It is only if you approach the Supreme through his double aspect of Sat and Chit-Shakti, double but inseparable, that the total truth of things can become manifest to the inner experience. The other side was developed by the Shakta Tantrics. The two together, the Vedantic and the Tantric truth unified, can arrive at the integral knowledge. (CWSA 29, p. 448)

According to Aurobindo, the Supreme Reality is not only the static impersonal Brahman (Sat) but also the dynamic personal God (Cit-Śakti). Śankara, he claims, erected his philosophy on the basis of his experience of the impersonal Brahman, mistakenly taking it to be the highest and most complete experience of the Absolute. As a result, Śankara affirmed the sole reality of nirguna Brahman and denied ultimate reality to Śakti and the world. Like Ramakrishna, Aurobindo claims that even after the Advaitic knowledge of the impersonal Brahman, there is a further stage of spiritual experience, which Ramakrishna called "vijñanna", in which one attains the greater and more expansive "integral knowledge" of both the static and dynamic aspects of the Divine Reality.

Aurobindo goes on to note that this claim is grounded in his own spiritual experiences:

Is the Mayavadin's featureless Brahman that Perfect, that Complete-is it the very Highest? Is there not or can there not be a higher than that highest, parātparam? That is not a question of logic, it is a question of spiritual fact, of a supreme and complete experience. The solution of the matter must rest not upon logic, but upon a growing, ever heightening, widening spiritual experience-an experience which must of course include or have passed through that of Nirvana and Maya, otherwise it would not be complete and would have no decisive value.

Now to reach Nirvana was the first radical result of my own Yoga. It threw me suddenly into a condition above and without thought, unstained by any mental or vital movement; there was no ego, no real world-only when one looked through the immobile senses, something perceived or bore upon its sheer silence a world of empty forms, materialised shadows without true substance. There was no One or many even, only just absolutely That, featureless, relationless, sheer, indescribable, unthinkable, absolute, yet supremely real and solely real ... I lived in that Nirvana day and night before it began to admit other things into itself or modify itself at all, and the inner heart of experience, a constant memory of it and its power to return remained until in the end it began to disappear into a greater Superconsciousness from above. But meanwhile realisation added itself to realisation and fused itself with this original experience. At an early stage the aspect of an illusionary world gave place to one in which illusion is only a small surface phenomenon with an immense Divine Reality behind it and a supreme Divine Reality above it and an intense Divine Reality in the heart of everything that had seemed at first only a cinematic shape or shadow. And this was no reimprisonment in the senses, no diminution or fall from supreme experience, it came rather as a constant heightening and widening of the Truth; it was the spirit that saw objects, not the senses, and the Peace, the Silence, the freedom in Infinity remained always with the world or all worlds only as a continuous incident in the timeless eternity of the Divine.

Now that is the whole trouble in my approach to Mayavada. Nirvana in my liberated consciousness turned out to be the beginning of my realisation, a first step towards the complete thing, not the sole true attainment possible or even 
a culminating finale. It came unasked, unsought for, though quite welcome. I had no least idea about it before, no aspiration towards it, in fact my aspiration was towards just the opposite, spiritual power to help the world and do my work in it, yet it came-without even a "May I come in" or a "By your leave". It just happened and settled in as if for all eternity or as if it had been really there always. And then it slowly grew into something not less but greater than its first self! How then could I accept Mayavada or persuade myself to pit against the Truth imposed on me from above the logic of Shankara? (CWSA 29, pp. 452-53)

Aurobindo obviously refers here to his Advaitic experience of nirvāna in 1908 when he was with the yogi Lele in Baroda, followed by his more "integral" experiences of God as the impersonal-personal Divine Reality manifesting as everything in the universe. He makes clear that his disagreement with Śankara is, first and foremost, spiritual rather than philosophical. That is, in his own case, the Advaitic experience of the "featureless Brahman" and the dreamlike unreality of the world was only a "first step" towards even richer and greater spiritual experiences. This subsequent integral realization of the impersonal-personal Divine did not negate his earlier Advaitic experience but "fused itself" with it. He then realized that the static and dynamic aspects of the Divine are equally real and that the world, far from being an illusion, is a real manifestation of Cit-Sakti.

Of course, a follower of Śankara might claim that Aurobindo's Advaitic experience of nirvikalpa samādhi in 1908 was, in fact, the highest spiritual experience, and that his subsequent experiences were lower experiences that occurred only after he had returned to the relative plane of the empirical world. However, in the passage just cited, Aurobindo anticipated precisely this objection and explained why his post-Advaitic realization of God in, and as, everything, was not "a diminution or fall from supreme experience". According to Aurobindo, he perceived the world not with his "senses" but with his "spirit", and the calm and freedom he experienced in nirvikalpa samädhi remained in his later spiritual experiences even as he saw the world anew as a real manifestation of God. Hence, he claims that his post-nirvikalpa realizations were not a fall from the supreme Advaitic heights but "a constant heightening and widening of the Truth".

In The Life Divine, Aurobindo similarly argues that the Advaitic realization of nondual Brahman is not the "final and absolute realisation", because "it is possible to travel beyond by a greater negation or a greater affirmation-to extinguish self in Non-Being or to pass through the double experience of cosmic consciousness and Nirvana of worldconsciousness in the One Existence to a greater Divine Union and Unity which holds both these realisations in its vast integral Reality" (CWSA 21-22, p. 487). According to Aurobindo, there are two ways of going even further than the Advaitic realization. On the one hand, one can radicalize the Advaitic method of "neti, neti" ("not this, not this") by following the Buddhist Śñnyavādins in negating even the nondual Self, thereby arriving at the more thoroughgoingly negative realization of total "Non-Being" (Śunya). On the other hand, one can deepen and expand the Advaitic realization of nondual Brahman by attaining "cosmic consciousness", the integral realization that the impersonal Brahman is also Cit-Śakti, which manifests as everything in the universe. It was, of course, precisely this affirmative method of going beyond Advaitic illusionism that Aurobindo himself pursued. Relatedly, he makes the very interesting argument that "spiritual realisations" can be just as "exclusive" as philosophical and religious dogmas, in that a particular realization may grant us insight into one aspect of the Infinite Divine Reality while excluding or marginalizing other aspects (CWSA 21-22, p. 400). He then goes on to claim that sectarian religious and spiritual philosophies tend to be based on such one-sided spiritual realizations:

but we err if we intellectualise them [distinct spiritual realisations] into sole truths - as when we assert that the Impersonal must be the one ultimate realisation and the rest creation of Maya or declare the Saguna, the Divine in its qualities, to be that and thrust away the impersonality from our spiritual experience. We have to see that both these realisations of the great spiritual seekers are equally valid in themselves, equally invalid against each other; they are one and the same 
Reality experienced on two sides which are both necessary for the full knowledge and experience of each other and of that which they both are. (CWSA 21-22, p. 401)

From Aurobindo's perspective, Śankkara's Advaita Vedānta makes the mistake of intellectualizing the Advaitic realization of nirguna Brahman in the state of nirvikalpa samādhi into a "sole truth", that is, by asserting the sole reality of nirguna Brahman and denying the ultimate reality of saguna Brahman and the world. Conversely, many theistic traditions, including Rāmānuja's Viśiștādvaita Vedānta, Madhva's Dvaita Vedānta, as well as orthodox forms of Judaism, Christianity, and Islam, make the mistake of affirming the sole reality of the personal God with qualities while denying the existence of an impersonal Absolute. Following Ramakrishna, Aurobindo argues that the spiritual realizations at the basis of both Advaitic and theistic philosophies are complementary rather than conflicting, since they provide insight into different, but equally real, aspects of "one and the same Reality".

Proponents of Śankara, however, could object that Aurobindo attacks a straw-man rather than Śankara himself, who generally appealed to the Upanisads rather than to his own spiritual experiences in support of his Advaitic standpoint (Comans 1993; Rambachan 1994, pp. 113-15). Indeed, Śankara sometimes claimed that the Upaniṣads are the only valid source of knowledge of Brahman. For instance, in his commentary on Brahmasütra 2.1.6, Śankara declared that Brahman "is to be known through scripture alone [āgamamātra]" (translation mine). Moreover, none of the ten major Upanișads upon which Śankara commented contain the term "samādhi" (Comans 1993, p. 22).

How might we defend Aurobindo against this objection? First, we could point out that Śankara, in his commentary on Brahmasūtra 1.1.2, explicitly claims that "Vedic scripture [śruti] etc., as well as spiritual experience [anubhava] etc., are valid means of knowing Brahman as far as possible; for the knowledge of Brahman culminates in anubhava, and it relates to an existing entity" (BSBh 1.1.2,16). ${ }^{4}$ Many scholars have interpreted this statement to mean that both scripture and spiritual experience (anubhava) are valid means of knowing Brahman, and that scriptural knowledge of Brahman culminates in the direct experience of Brahman (Sharma 1992; Phillips 2001; Devaraja 1962, pp. 36-71; Murty 1959, p. 112). ${ }^{5}$ If this is what Śankara means, then Aurobindo's objection that the Advaitic anubhava of nirguna Brahman is valid but one-sided may very well apply to Śankara's philosophy.

Moreover, even if we concede that Śankara generally emphasizes scripture rather than spiritual experience as the main source of the knowledge of Brahman, Aurobindo argues in detail that the Vedic hymns, Iśā Upanișad, Kena Upanișad, and Bhagavad-Gĩtā do not support Śankkara's Advaitic philosophy (Maharaj 2015; Maharaj 2020a; Medhananda 2021). In particular, Aurobindo contends that the Upanișads and Gìt $\bar{a}$ hold that Brahman is both nirguna and saguna, and that this world is a real manifestation of Brahman. Moreover, he claims that the Gìtā embraces multiple forms of spiritual practice, including Jñāna-Yoga, Bhakti-Yoga, and Karma-Yoga, as equally effective paths to spiritual knowledge (Maharaj 2015). By contrast, Śankara interprets the Gìtā as holding that Jñāna-Yoga is the only direct path to spiritual knowledge, while Karma-Yoga and Bhakti-Yoga lead indirectly to spiritual knowledge by purifying the mind and thereby making one eligible to practice Jñāna-Yoga. ${ }^{6}$

It is also important to note that while Śankara himself did not place much emphasis on spiritual experience, a number of mainstream post-Śankara Advaitic texts, including Vivekacūụ̄maṇi, Pañcadaśi, Jīvanmuktiviveka, Vedāntasāra, and Aparokṣānubhūti, strongly emphasize the necessity of nirvikalpa samādhi. For instance, verse 365 of Vivekacūdāmani declares: "It is only through nirvikalpa samädhi, and not otherwise, that the truth of Brahman is clearly and definitely known" (nirvikalpakasamādhinā sphutam brahmatattvam avagamyate dhruvam I nānyathā...) (Madhavananda 1921, p. 161). Hence, even if Aurobindo's experiential critique of Advaita Vedānta arguably does not apply to Śankkara, it still applies to the many post-Śankara Advaitins who hold that nirvikalpa samādhi is necessary for, if not tantamount to, the knowledge of Brahman. 
However, proponents of Śankara could respond to Aurobindo's experiential critique of Advaita Vedānta in a different way by arguing that it is merely subjective. Aurobindo no doubt claimed to have realized both the personal and impersonal aspects of the Divine and to have experienced everything in the world as a real manifestation of the Divine. But why should we believe him? And what reason do we have for thinking that his alleged spiritual experiences have epistemic value?

The question of the epistemic value of spiritual experience is a complicated one that I have discussed at length elsewhere (Maharaj 2018, chp. 6; Medhananda Forthcoming a, chps. 5-6; Medhananda Forthcoming b). For present purposes, I only briefly note that Aurobindo himself defended the epistemic value of spiritual experience on the basis of what Stephen Phillips calls a "parallelism thesis" - the thesis that sense-perceptual testimony and mystical testimony are parallel (Phillips 1986, pp. 5-53). According to Aurobindo, just as the "world of Matter is affirmed by the experience of the physical senses", the existence of supraphysical realities is affirmed by the experience of "senses which are supraphysical" (CWSA 21-22, p. 21). Hence, he argues that "the truth of great ranges of experience whose objects exist in a more subtle substance and are perceived by more subtle instruments than those of gross physical Matter, claims in the end the same validity as the truth of the material universe" (CWSA 21-22, p. 22). For Aurobindo, then, just as ordinary people are typically justified in taking their perception of a putative sense-object-say, a piece of paper-as evidence for believing that the sense-object exists, credible mystics are equally justified in taking their perception of putatively supersensory objects, such as God or the Self, as evidence for believing that those supersensory objects exist. As I have discussed elsewhere (Maharaj 2018, chp. 6; Medhananda Forthcoming a, chps. 5-6), numerous philosophers of religion have followed Aurobindo in attempting to justify the epistemic value of mystical experience on the basis of a parallelism between mystical experience and sensory experience. ${ }^{7}$

Finally, it must be remembered that Aurobindo's critique of Advaita Vedānta has three basic dimensions. His experiential critique of Advaita Vedānta, far from standing alone, has to be understood in conjunction with his nonillusionistic interpretations of the Vedic hymns and Vedāntic scriptures, as well as his philosophical criticisms of Advaita metaphysics, which is discussed in the next section.

\section{Aurobindo's Philosophical Critique of Advaita Vedānta}

At various points in The Life Divine, Aurobindo raises a number of subtle philosophical objections to Advaita Vedānta. In this section, I focus on his main objections to the key Advaitic doctrines of nirguna Brahman and māyan. He argues that Advaita Vedāntins end up in a "logical impasse" by holding that nirguna Brahman is utterly transcendent and, therefore, does not have the capacity to manifest as the world (CWSA 21-22, p. 391). According to Aurobindo, Advaitins thereby make the mistake of imprisoning Brahman in its own transcendence. ${ }^{8}$ As he puts it, Advaitins speak of Brahman "as not only not bound by the limitations of the relative, but as if it were bound by its freedom from limitations, inexorably empty of all power for relations and in its nature incapable of them, something hostile in its whole being to relativity and its eternal contrary" (CWSA 21-22, p. 391). Aurobindo traces this Advaitic assumption to "the mind's habit of oppositions, of thinking by distinctions and pairs of contraries" (CWSA 21-22, p. 391). Advaitins, as a result of this dichotomous thinking, mistakenly assume that the impersonality and transcendence of Brahman are strictly incompatible with personality and a capacity to manifest.

Aurobindo's criticism of Advaita Vedānta may remind us of a similar criticism made by Kashmiri Shaiva philosophers many centuries earlier. According to Abhinavagupta, by failing to accept the reality of dynamic Śakti, Advaitins end up reducing Brahman to the status of an insentient entity. As Abhinavagupta puts it, "If the Highest Reality did not manifest infinite variety but remained cooped up within its solid singleness, it would be neither the Highest Power nor consciousness, but something like a jar" (cited in Singh (1985, p. 27). ${ }^{9}$ Kashmiri Shaivites like Abhinavagupta hold that the ultimate reality Paramaśiva, 
by means of His svātantrya-śakti (absolute freedom and power), becomes various individual subjects by "subjecting Himself to $M \bar{a} y \bar{a}$ and putting on the five kañcukas or cloaks which limit His universal knowledge and power" (Singh 1980, p. 13). Aurobindo, like Kashmiri Shaivites, holds that the ultimate reality is not only the static, transcendent Brahman but also the dynamic Cit-Śakti, which manifests as everything in the universe. Aurobindo also appeals to God's "absolute omnipotence", which comes very close to the Kashmiri Shaivite doctrine of svātantrya-śakti. As Aurobindo puts it, God's power of "self-limitation"-His ability to limit Himself by manifesting as ignorant beings-is "not . . . a sign, proof or reality of weakness, but a sign, proof, reality — the greatest possible-of an absolute omnipotence" (CWSA 21-22, p. 420).

In spite of these striking similarities, I believe Aurobindo's critique of Advaita Vedānta differs from Abhinavagupta's critique in one important respect. Abhinavagupta's argument against Advaita Vedānta is more of an external than an internal critique: he criticizes the Advaitic conception of nirguna Brahman from his own Kashmiri Shaivite standpoint, according to which the ultimate reality is Śiva-Śakti. By contrast, Aurobindo presents his argument as an internal critique of Advaita Vedānta. He argues that the Advaitic assumption that nirguna Brahman lacks the capacity for manifestation results in insuperable logical difficulties. His argument, contained on pp. 391-92 of The Life Divine, is roughly as follows. According to Advaita Vedānta, nirguṇa Brahman alone exists and, therefore, neither the universe, individual souls, nor the personal God exist from the ultimate standpoint. At the same time, Advaitins do acknowledge the apparent existence of this world of multiplicity, which they explain by appealing to the doctrine of $a d h y \bar{a} s a$ (illusory superimposition): as a result of our ignorance of Brahman, we mistakenly superimpose this world of names and forms onto nirguna Brahman, just as someone might mistakenly superimpose an illusory snake onto a real rope. But who, exactly, engages in this mistaken superimposition? According to Advaitins, the jīva (individual soul) does. But what exactly is this jīva? Advaitins hold that the jīva is itself an illusory superimposition on Brahman and, hence, "not a real reality" (CWSA 21-22, p. 392). Ultimately, then, Advaitins are forced to concede that Brahman itself, as the illusory individual soul, makes the mistake of superimposing this illusory world on itself. However, as Aurobindo points out, "By this explanation nothing is explained; the original contradiction stands where it was, unreconciled, and we have only stated it over again in other terms" (CWSA 21-22, p. 392). That is, Advaitins end up contradicting themselves by holding, on the one hand, that nirguna Brahman is the sole reality and, on the other hand, that this very Brahman, as the jīva, deludes itself by superimposing on itself this illusory world of multiplicity.

Aurobindo provocatively suggests that Advaitins land in this "logical impasse" because they make "the error of making too simple and rigid and extending too far the law of contradictions" (CWSA 21-22, p. 391). Aristotle first formulated the law of noncontradiction as follows: "It is impossible for the same thing to belong and not to belong at the same time to the same thing and in the same respect" (Metaphysics IV.3.1005b19-20; italics added). Since Aurobindo studied Greek and Latin at Cambridge University, he had likely read some of Aristotle's work. Notice that in Aurobindo's own formulation of the law of noncontradiction, he emphasizes Aristotle's "in the same respect" clause: "The law of contradictions here is only valid in so far as two different and opposite statements cannot be true of the same thing at the same time, in the same field, in the same respect, from the same point of view and for the same practical purpose" (CWSA 21-22, p. 398; italics added). In light of this formulation, I suggest that what Aurobindo means when he says that Advaitins make the law of non-contradiction "too simple and rigid" is that they drop the "in the same respect" clause from Aristotle's formulation. In doing so, Advaitins overlook the possibility that the Divine Reality can be impersonal in one aspect and personal in another aspect, static in one aspect and dynamic in another, transcendent in one aspect and immanent in another.

Of course, Advaitins would likely respond that this very talk of "aspects" is illegitimate: if Brahman has multiple aspects, then it would be internally differentiated-in 
traditional philosophical terminology, it would be subject to svagatabheda-and, hence, its nonduality would be compromised. However, I think this is precisely where the second part of Aurobindo's objection becomes relevant: Advaitins assume that Brahman's nonduality is incompatible with its having multiple aspects, in part because they extend "too far the law of contradictions". That is, they wrongly project the limitations of the finite human intellect onto the Absolute:

It looks as if, by attempting to arrive at an explanation by means of intellectual reasoning, we have only befogged ourselves by the delusion of our own uncompromising logic: we have imposed on the Absolute the imposition which our too presumptuous reasoning has practised on our own intelligence; we have transformed our mental difficulty in understanding the world-manifestation into an original impossibility for the Absolute to manifest itself in world at all. But the Absolute, obviously, finds no difficulty in world-manifestation and no difficulty either in a simultaneous transcendence of world-manifestation; the difficulty exists only for our mental limitations which prevent us from grasping the supramental rationality of the coexistence of the infinite and the finite or seizing the nodus of the unconditioned with the conditioned. For our intellectual rationality these are opposites; for the absolute reason they are interrelated and not essentially conflicting expressions of one and the same reality. (CWSA 21-22, p. 392)

According to Aurobindo, what might appear to be opposites or contradictories to the finite intellect, such as personality and impersonality, transcendence and immanence, dynamism and stasis, are, in fact, complementary aspects of the Absolute when seen from the standpoint of the "supramental rationality" or what he elsewhere calls the "logic of the infinite" (CWSA 21-22, p. 343). ${ }^{10}$

In The Life Divine, Aurobindo also presents a very subtle and lengthy critique of the Advaitic doctrine of $m \bar{a} y \bar{a}$ (CWSA 21-22, pp. 457-91). He was, of course, by no means the first to pinpoint this doctrine as the Achilles heel of Advaita Vedānta. In fact, Śankara himself seemed to have been aware of the difficulty of explaining the ontological status and locus of avidyā (ignorance). In his commentary on Brahmasūtra 4.1.3, Śankara addresses these issues in a passage remarkable for its slipperiness:

Opponent: "Who is it then that is unenlightened?"

Vedāntin: "Unenlightenment belongs to you who are asking".

Opponent: "But the scriptures state that I am God".

Vedāntin: "If that is so, you are already an enlightened man, and so nobody has unenlightenment". (translation mine) $)^{11}$

In response to the opponent's question regarding the locus of ignorance, Śankara initially declares that ignorance belongs to the questioner himself. Sankara's view, then, seems to be that the individual soul (jīva) is the locus of ignorance. However, the opponent counters by reminding Śankara that the jīva, according to Advaita Vedānta, is none other than Brahman. Śankara then changes tack by claiming that ignorance is, in fact, nonexistent and hence belongs to no one. Paul Hacker (1995, p. 66) notes that Śankara's answers are "not philosophically exact" but "pedagogically compelling". In a similar vein, Daniel Ingalls (1953, p. 69) argues that Śankkara tackles the problem of avidya "not by solving but by avoiding it".

Not surprisingly, shortly after Śankara's time, different subschools of Advaita Vedānta defended conflicting views on the question of the status and locus of avidya $\bar{a}$. According to the Bhāmatī school, the jīva is the locus of ignorance, since Brahman cannot possibly be subject to ignorance. However, according to the Vivarana school, the jiv the locus of ignorance, since it is itself the product of ignorance; hence, Brahman must be the locus of ignorance. Since Sankara's stance on avidyā was vague and ambiguous, the followers of both the Bhāmatī and Vivaraṇa schools argued that Śankara supported their own standpoint. 
The Viśiștādvaita Vedāntin Rāmānuja and his followers argued that these internecine debates about avidyā within the fold of Advaita Vedānta reflect a fatal aporia in the Advaitic doctrine of avidyā: Advaitins account for this illusory world by appealing to ignorance (avidy $\bar{a})$, yet they are unable to explain satisfactorily how either the individual soul or Brahman could be subject to ignorance. In turn, Advaita philosophers like Madhusūdana Sarasvatī and Citsukha attempted to refute such objections to their doctrine of avidya and to defend its logical tenability (Grimes 1990).

As far as I am aware, there is no evidence that Aurobindo studied these traditional intra-Vedāntic debates about the Advaitic doctrine of avidyā. Nonetheless, it is possible that he was aware of these debates, if only in a general way. While he raises some objections to Advaita Vedānta that are similar to those of Rāmānuja and others, Aurobindo's critique of the Advaitic doctrine of $m \bar{a} y \bar{a}$ is quite subtle and original in a number of respects. He presents an elaborate argumentative dialectic in which he critically examines a variety of possible Advaitic positions on the nature of $m \bar{a} y \bar{a}$, ranging from the doctrine of anirvacanīyatā of post-Śankara Advaitins, the radical illusionism of Gauḍapāda and others, as well as the "qualified illusionism" of Śankara. ${ }^{12}$

Aurobindo's dialectic begins with a simple question: if, according to Advaita Vedānta, the sole reality is the impersonal nondual Brahman and everything else is an illusion, "what then is the relation between the Reality and the Illusion?" (CWSA 21-22, p. 458). That is, why should an illusory world appear to us at all? And how exactly does this world-illusion relate to Brahman? He first considers the mainstream post-Śankara Advaitic response to these questions: this illusory world is the product of $m \bar{a} y \bar{a}$, which is "neither real nor unreal" (anirvacanīya) (CWSA 21-22, p. 458). ${ }^{13}$ According to post-Śańkara Advaitins, māyā cannot be real, since the sole reality is Brahman; but on the other hand, it cannot be entirely unreal, since an illusory world does appear to us and is itself a superimposition on Brahman and, hence, "is based in a way on the one Reality" (CWSA 21-22, p. 458).

However, Aurobindo points out that this Advaitic appeal to māya raises another question: "how comes this illusion to intervene in Brahman-existence?" (CWSA 21-22, pp. 458-59). If Brahman is the sole reality, how does māya arise at all? According to Aurobindo, there are only two possible answers to this question: either (a) the jīva perceives $m \bar{a} y \bar{a}$ or (b) Brahman perceives māyā. As noted earlier, (a) and (b) represent the Bhāmatī and Vivarana positions respectively, though Aurobindo does not say so. Rāmānuja, in his Śribhāṣya, rejected answer (a) by arguing that it involves the fallacy of mutual dependence (anyonyāśraya): the jīva cannot be the locus of ignorance, since it is the product of ignorance (Grimes 1990, p. 27). Aurobindo rejects answer (a) on essentially the same grounds as Rāmānuja: the jīva cannot be the perceiver of $m \bar{a} y \bar{a}$, since the jīva "is himself phenomenal and unreal, a creation of Maya" (CWSA 21-22, p. 459).

On the other hand, if we accept answer (b), then we are faced with another difficult question: how can Brahman, which is ever perfect and nondual, be subject to illusion? According to Aurobindo, there are only three possible answers to this question from an Advaitic standpoint. First, māy $\bar{a}$ can be understood as Brahman's capacity for subjective experiences, which would be real as experiences but ultimately unreal since they do not correspond to anything in Brahman's being (CWSA 21-22, p. 460). However, this view is untenable, both because it is based on the false assumption that the distinction between subjective and objective experience that is applicable to us finite creatures is equally applicable to a perfect being, and because it implies a duality between "Brahman being" and "Brahman consciousness", which would contradict the nonduality of Brahman (CWSA 21-22, p. 461). Second, māyā can be understood as Brahman's power of imagining unreal entities. However, this view is also untenable, since imagination is only a necessity for ignorant creatures who have to supplement their ignorance with "imaginations and conjectures" (CWSA 21-22, p. 460).

The only remaining possibility for the Advaitin is to hold that Brahman has a "dual consciousness" (CWSA 21-22, p. 460), "one conscious of the sole Reality, the other conscious of the unrealities to which by its creative perception of them it gives some kind of apparent 
existence" (CWSA 21-22, p. 459). However, we then have to inquire into the precise nature of this dual consciousness. One might explain Brahman's dual consciousness as a "dual power of Knowledge-Ignorance" (CWSA 21-22, p. 461). However, this position would entail that Brahman is subject to ignorance, which would contradict the very nature of Brahman as perfect and infinite Pure Consciousness. To avoid this difficulty, one might claim that Brahman, though perfect, chooses to project a "universe of illusions" (CWSA $21-22$, p. 462). In this case, it would only be the "Nature-mind" that is subject to delusion, not Brahman itself (CWSA 21-22, p. 462). However, we would then have to ask why Brahman, as nondual Pure Consciousness, would choose to project a world of illusions in the first place. It seems difficult to explain why Brahman, which is perfect and complete in itself, would have the need or desire to erect an illusory world. As Aurobindo puts it, "it seems incredible that the sole power of the Reality should be to manifest something contrary to itself or to create nonexistent things in an illusory universe" (CWSA 21-22, p. 463). ${ }^{14}$ He concludes, therefore, that the post-Śankara Advaitic attempt to account for this world-illusion by appealing to anirvacanīya māya is untenable.

Aurobindo then considers a different Advaitic strategy for explaining this worldillusion: instead of characterizing māya as neither real nor unreal, some Advaitins-like Gauḍapāda and, at times, Śankara—hold that māya is simply nonexistent (CWSA 21-22, p. 463). ${ }^{15}$ However, Aurobindo argues that this appeal to the "absolute unreality" of māya results in one of two difficulties (CWSA 21-22, p. 463). On the one hand, it could amount to nothing more than a "sophism which means nothing", since the world, even if it is unreal, does appear to us, and it is precisely this appearance of the world that calls for explanation (CWSA 21-22, p. 463). On the other hand, the thesis of the absolute unreality of māya may mean "too much, since in effect it gets rid of all relation of Maya to Brahman by affirming her as an independent absolute nonreality along with the universe created by her" (CWSA $21-22$, p. 463). In other words, if Brahman is completely unrelated to māa $\bar{a}$, then $m \bar{a} y \bar{a}$ becomes a nonexistent entity alongside Brahman, which is the cause of the world-illusion. In that case, Advaita collapses into a dualism of Brahman and māya..$^{16}$

If the Advaitin adopts this latter position, holding that Brahman has nothing to do with $m \bar{a} y \bar{a}$, then the perceiver of this illusory universe must be the individual being rather than Brahman. However, since both the individual being and the entire universe are themselves products of ignorance, the very pursuit of "salvation from Maya" becomes pointless, since everything is "of an equal unreality and unimportance" (CWSA 21-22, p. 464). To avoid this difficulty, the Advaitin may take a "less rigid standpoint", arguing that while "Brahman as Brahman has nothing to do with Maya,... Brahman as the individual percipient ... has entered into Maya", and hence, its withdrawal from māya is "an act of supreme importance" (CWSA 21-22, p. 464). However, this position has two serious problems. First, it ascribes a "dual being" to Brahman, which would compromise its nonduality (CWSA 21-22, p. 464). Second, it grants a certain degree of reality to the individual being in māya in order to secure the importance of salvation, thereby contradicting the Advaitic thesis of the sole reality of nondual Brahman.

To avoid these problems, the Advaitin may modify this position, holding that "our individuality is unreal, it is Brahman who withdraws from a reflection of itself in the figment of individuality and its extinction is our release, our salvation" (CWSA 21-22, p. 465). Aurobindo seems to have in mind the pratibimba doctrine of the Vivarana school of Advaita, according to which the jiva is an illusory "reflection" (pratibimba) of Brahman. However, this pratibimba doctrine fails to provide a plausible explanation of who exactly profits by salvation. After all, Brahman is "ever free", so it cannot be subject to bondage and, therefore, has no need for salvation. On the other hand, the individual being-understood as a mere "reflection" - also cannot profit by salvation, since a reflection "is not a thing that can need salvation" (CWSA 21-22, p. 465).

If the Advaitin responds by claiming that the individual being is a "conscious reflection" that can actually suffer and profit by salvation, then we would have to ask: "whose is the consciousness that so suffers in this fictitious existence"? (CWSA 21-22, p. 465). Once 
again, the Advaitin is forced to accept a "dual consciousness for Brahman", a consciousness free from illusion and a consciousness subject to illusion (CWSA 21-22, p. 465). However, as we have seen, Aurobindo has already shown that there is no plausible way of explaining Brahman's dual consciousness within the framework of Advaita Vedānta.

Aurobindo then considers an alternative position, according to which the jiv $a$ and the universe are unreal but $m \bar{a} y \bar{a}$, through its superimposition on Brahman, acquires a "certain reality" which it lends to the jī $a$ for the duration of its "experience in the cosmic Illusion" (465). Again, however, the same problem arises, since we have to ask: "for whom is the experience valid" (465)? If the jiv $a$ is illusory, then it cannot be subject to suffering and cannot benefit from salvation from suffering. Hence, we have to assume that Brahman has either a dual consciousness or a dual being - with one aspect of its consciousness or being really involved in $m \bar{a} y \bar{a}$, if only temporarily.

Aurobindo concludes that all illusionistic attempts to explain the relationship between Brahman and this world-appearance end up in self-contradiction: they "bring[] in, in effect, a self-contradictory dual status of consciousness of the One to annul a self-contradictory dual status of being of the One" (CWSA 21-22, p. 470). Since Advaita Vedāntins reject the possibility that Brahman has a dual ontological status as the static, impersonal Absolute and as the personal, dynamic Śakti, they are forced, in the end, to admit that some aspect of Brahman is nonetheless the perceiver of the illusion, thereby contradicting the nondual metaphysics of Advaita Vedānta.

According to Aurobindo, Śankara tries to avoid this difficulty by championing a "qualified Illusionism", which distinguishes "two orders of reality, transcendental and pragmatic" (CWSA 21-22, p. 478). For Śankkara, this world (jagat), individual souls (jīvas), and the personal God (īśvara) all have empirical or pragmatic (vyāvahārika) reality, but only the impersonal nondual Brahman has absolute (pāramārthika) reality. However, the key question is: what is the precise ontological status of empirically real entities? Aurobindo acknowledges that different commentators have interpreted Śankara's answer to this question in different ways (CWSA 21-22, p. 478). In a letter to a disciple, Aurobindo wrote: "We are even told by some that he [Śankara] was no Mayavadin at all although he has always been famed as the greatest exponent of the theory of Maya, but rather, the greatest Realist in philosophical history" (CWSA 29, p. 391) ${ }^{17}$ Nonetheless, Aurobindo thinks that Śankara's view, as reflected in his scriptural commentaries, is actually quite clear. Śankara, Aurobindo claims, conceives empirically real entities as an "unreal reality, real only to our ignorance, unreal to any true knowledge" (CWSA 21-22, p. 472). ${ }^{18}$ That is, Sankara takes the empirical standpoint to be tantamount to the standpoint of ignorance: this world, our own individuality, and the personal God, appear real to us so long as we remain ignorant of nondual Brahman, but the moment we attain the knowledge of Brahman we realize that we were mistaken all along in taking the world, the personal God, and individual beings to be real. There are, indeed, numerous passages from Śankara's commentaries that support Aurobindo's interpretation. For instance, in his commentary on Brahmasūtra 2.1.33, Śankara states that "Vedic statements about creation do not concern ultimate reality; it must not be forgotten that such texts have only empirical validity, since they pertain to names and forms conjured up by ignorance." ${ }^{19}$ Likewise, in his commentary on Brahmasūtra 2.1.14, Śankara explains the ontological status of íśvara as follows: "Thus iśvara's rulership, omniscience, and omnipotence are dependent on the limiting adjuncts conjured up by ignorance; but from the ultimate standpoint, such terms as 'the ruler,' 'the ruled,' 'omniscience,' etc. cannot be used with regard to the Ātman in Its true nature after the removal of all limiting adjuncts through knowledge". ${ }^{20}$ Accordingly, Aurobindo argues that Śańkara's "qualified" illusionism, based on a two-tier ontology, ends up collapsing into a thoroughgoing Advaitic illusionism, which is fraught with the philosophical problems Aurobindo already outlined earlier. As he puts it, "the concession accorded [by Śankara] with one hand is taken away by the other" (CWSA 21-22, p. 472).

In light of the insuperable philosophical problems facing both the illusionist and the qualified illusionist forms of Advaita philosophy, Aurobindo argues that it is more 
reasonable to reject illusionism in favor of his own "realistic" Advaita doctrine, according to which the Divine Reality is not only the static nirguna Brahman but also the dynamic Śakti, which actually manifests as everything in the universe. As he puts it, "We begin to envisage the Reality as an eternal oneness, status, immutable essence of pure existence supporting an eternal dynamis, motion, infinite multiplicity and diversity of itself" (CWSA 21-22, p. 470). From Aurobindo's perspective, Advaita Vedāntins took a wrong turn when they dismissed as self-contradictory the possibility that Brahman has a dual being as nirguna and saguna. Aurobindo argues that the notion of an impersonal-personal Divine Reality is perfectly coherent, since personality and impersonality are different aspects of the same Reality. Moreover, his own spiritual experiences confirmed for him the reality of the impersonal-personal Divine Reality.

\section{Conclusions: Aurobindo's Significance for the Current Ecological Crisis}

Aurobindo's criticisms of Advaita Vedānta and his embrace of a life-affirming Integral Advaita philosophy have proven to be quite prescient and influential. In the past few decades, scholars have taken Aurobindo's lead in beginning to emphasize that the Advaita Vedānta of Śankara and his followers is only one of many forms of Advaita philosophy within the Indian tradition. Exciting work is now being done on a range of nonillusionistic and life-affirming philosophical traditions of Advaita, including not only Sri Aurobindo's Integral Advaita (Phillips 1986; Padiyath 2014; Prince 2017) but also Vallabha's Śuddhādvaita Vedānta (Narain 2004; Smith 2011), Sri Ramakrishna's Vijñāna Vedānta (Maharaj 2018), Swami Vivekananda's Practical Vedānta (Bhushan and Garfield 2017, pp. 221-23; Maharaj 2020b), Śaiva Nondualism (Ratié 2017; Nemec 2011), and Śākta Tantra (Sherma 2010; Lidke 2017).

Like Aurobindo, numerous contemporary scholars have begun to question the philosophical cogency of Advaita Vedānta and to probe its limitations and weak points. In the philosophy of mind, debates have been raging about how to tackle what David Chalmers (1995) has famously dubbed the "hard problem of consciousness", i.e., the problem of explaining the qualitative, "what-it-is-like" character of consciousness. The philosopher Miri (Albahari 2019a, 2019b) draws upon Advaita Vedānta to argue that a nondual theory of Pure Consciousness is best equipped to address the hard problem of consciousness. Very recently, however, a number of philosophers have argued that the illusionist metaphysics of Advaita Vedānta renders it incapable of explaining the conscious experiences of empirical individuals, the very existence of which is denied from the ultimate standpoint (Gasparri 2019; Vaidya 2020). Indeed, I have argued elsewhere that the world-affirming Advaita philosophies of Vivekananda and Aurobindo offer a more compelling cosmopsychist theory of consciousness, according to which the Infinite Divine Reality actually manifests as individual consciousnesses through a process of self-involution (Medhananda Forthcoming a, chps. 9-10; Medhananda Forthcoming b).

By way of concluding this article, I would like to focus briefly on a different, but very important, contemporary issue: namely, environmental ethics. Scholars like Eliot Deutsch (1970, 1989), Anantanand Rambachan (1989), and Lina Gupta (1994) have argued that Advaita Vedānta - in its emphasis on the oneness of all things and creatures-provides a strong metaphysical basis for the "reverence of all living things", since everything in nature has "intrinsic spiritual worth" (Deutsch 1970, pp. 81-83).

Recently, however, Lance Nelson (2010, p. 64) has made a persuasive case that "Advaita Vedānta is not the kind of nondualism that those searching for ecologically supportive modes of thought might wish it to be". The Upanișads themselves undoubtedly emphasize the divinity of everything, as in the famous declaration in Chāndogya Upanișad 3.14.1: "Everything is Brahman" (sarvam khalvidam brahma). Nonetheless, Nelson rightly points out that Śankara interprets this Upanișadic statement to mean that all names and forms are a false "superimposition" on Brahman, which alone is real (Nelson 2010, p. 71). He further notes that the world-negating metaphysics of Advaita Vedānta entails a "radical ontological devaluation" of nature-insofar as nature is ultimately unreal—and an attitude 
not of reverence but of disgust, or at least indifference, toward the world (Nelson 2010, p. 68).

According to Nelson (2010, p. 70), in order to find a robust metaphysical basis for an ecological conscience, we need to turn to life-affirming forms of nondualism within the Indian tradition, including "Tantric nondualism, Mahāyāna Buddhism (especially in East Asia), and the teaching of Sri Aurobindo", as well as "the tantric Advaita of Ramakrishna ... and the Neo-Vedanta of Vivekananda". Nelson (2010, p. 71) aptly quotes Ramakrishna's teachings on vijñāna, the realization that nirguna Brahman is inseparable from Śakti, which "has become the universe and all its living beings". As I noted in Section 1, Ramakrishna's teachings on vijūāna played a formative role in shaping Aurobindo's own life-affirming Integral Advaita philosophy.

Building on Nelson's argument, I would suggest that Aurobindo's Integral Advaita furnishes a sophisticated metaphysical framework for grounding a genuine reverence for nature. In opposition to dualistic philosophies like those of Descartes and Sāmkhya, Aurobindo defends the Integral Advaitic view that everything in nature, from atoms to God-realized saints, is on an ontological continuum. Aurobindo's views on nature are grounded in his metaphysical thesis that the Cit aspect of the Divine Saccidannanda is the dynamic "Chit-Shakti" (CWSA 21-22, p. 196), or "Consciousness-Force", which is present, either in a latent or manifest form, in everything without exception. According to his doctrine of evolution, the Cit-Śakti that is involved in every entity down to the atom manifests to varying degrees at different phases of the still ongoing evolutionary process. On this basis, he argues that life is present not only in animals and plants but also in apparently "inanimate" matter (CWSA 21-22, pp. 185-99). Plants, he claims, have a "nervous system" (CWSA 21-22, p. 197): "When the sensitive plant shrinks from a contact, it appears that it is nervously affected, that something in it dislikes the contact and tries to draw away from it; there is, in a word, a subconscious sensation in the plant, just as there are, as we have seen, subconscious operations of the same kind in ourselves" (CWSA 21-22, p. 195). The main difference in the nervous systems of animals like us and of plants is that the "nervous responses" of animals are usually "attended with the mental response of conscious sensation" (CWSA 21-22, p. 194). Nonetheless, he points out that the absence of mental consciousness in plants does not make them any less "alive" than we are. ${ }^{21}$

Aurobindo then takes this argument one step further by suggesting that there are parallel signs of life in all matter:

It is becoming possible now to conceive that in the very atom there is something that becomes in us a will and a desire, there is an attraction and repulsion which, though phenomenally other, are essentially the same thing as liking and disliking in ourselves, but are, as we say, inconscient or subconscient. This essence of will and desire are evident everywhere in Nature and, though this is not yet sufficiently envisaged, they are associated with and indeed the expression of a subconscient or, if you will, inconscient or quite involved sense and intelligence which are equally pervasive. Present in every atom of Matter all this is necessarily present in every thing which is formed by the aggregation of those atoms; and they are present in the atom because they are present in the Force which builds up and constitutes the atom. That Force is fundamentally the Chit-Tapas or Chit-Shakti of the Vedanta, consciousness-force, inherent conscious force of conscious-being, which manifests itself as nervous energy full of submental sensation in the plant, as desire-sense and desire-will in the primary animal forms, as self-conscious sense and force in the developing animal, as mental will and knowledge topping all the rest in man. Life is a scale of the universal Energy in which the transition from inconscience to consciousness is managed; it is an intermediary power of it latent or submerged in Matter, delivered by its own force into submental being, delivered finally by the emergence of Mind into the full possibility of its dynamis. (CWSA 21-22, pp. 196-97) 
Even atoms, he notes, exhibit attraction and repulsion, which is "essentially the same thing as liking and disliking in ourselves". Life is entirely "latent or submerged" in matter, manifest to a greater extent in the "submental being" of plants, and fully manifest in the mental life of higher animals. Life itself is an "intermediary power" of the Divine Cit-Śkti in that it facilitates the evolutionary process at both the biological and spiritual levels.

Aurobindo realizes, however, that this argument by analogy for the presence of life in matter is not convincing on its own. Accordingly, he presents a subtle argument for the "logical necessity" of life in matter (CWSA 21-22, p. 197) on the basis of the uncontroversial premise that at some point in the distant past, organic life must have evolved out of matter. ${ }^{22}$ His argument runs as follows:

Evolution of Life in matter supposes a previous involution of it there, unless we suppose it to be a new creation magically and unaccountably introduced into Nature. If it is that, it must either be a creation out of nothing or a result of material operations which is not accounted for by anything in the operations themselves or by any element in them which is of a kindred nature; or, conceivably, it may be a descent from above, from some supraphysical plane above the material universe. The two first suppositions can be dismissed as arbitrary conceptions; the last explanation is possible, and it is quite conceivable and in the occult view of things true that a pressure from some plane of Life above the material universe has assisted the emergence of life here. But this does not exclude the origin of life from Matter itself as a primary and necessary movement; for the existence of a Life-world or Life-plane above the material does not of itself lead to the emergence of Life in matter unless that Life-plane exists as a formative stage in a descent of Being through several grades or powers of itself into the Inconscience with the result of an involution of itself with all these powers in Matter for a later evolution and emergence. Whether signs of this submerged life are discoverable, unorganised yet or rudimentary, in material things or there are no such signs, because this involved Life is in a full sleep, is not a question of capital importance. The material Energy that aggregates, forms and disaggregates is the same Power in another grade of itself as that Life-Energy which expresses itself in birth, growth and death, just as by its doing of the works of Intelligence in a somnambulist subconscience it betrays itself as the same Power that in yet another grade attains the status of Mind; its very character shows that it contains in itself, though not yet in their characteristic organisation or process, the yet undelivered powers of Mind and Life. Life then reveals itself as essentially the same everywhere from the atom to man, the atom containing the subconscious stuff and movement of being which are released into consciousness in the animal, with plant life as a midway stage in the evolution. Life is really a universal operation of Conscious-Force acting subconsciously on and in Matter ... (CWSA 21-22, pp. 197-98)

His argument here takes the form of an inference to the best explanation, which can be reconstructed roughly as follows:

1. At some point in our evolutionary past, life evolved from matter.

2. There are only two possible ways that life could have evolved from matter. Either life was already latent or "involved" in matter, or life was a new creation that emerged from nonliving matter.

3. There are only three possible explanations of how life could have emerged anew from nonliving matter. (a) Life was created out of nothing, or (b) life emerged from material operations, none of which have any properties that could account for life's emergence, or (c) life emerged from nonliving matter through the intervention of some supraphysical force above the material universe.

4. Since something cannot come from nothing, (a) and (b) can be excluded as possibilities.

5. Even if (c) is true, (c) presupposes the involution of life in matter. 
6. Therefore, the best explanation of the fact that life emerged from matter is that life was involved in matter.

This argument strikes me as largely plausible, though I think its primary weak point is premise 5. I don't think Aurobindo has done enough to establish that (c) necessarily presupposes the involution of life in matter. The possibility he either overlooks, or too quickly dismisses, is that some higher power could have directly intervened so as to make it possible for life to emerge from nonliving matter. Aurobindo assumes that the supraphysical plane is a "Life-world or Life-plane", and then argues that that Life-plane could not bring about the evolution of life from matter unless the Life-plane was already latent in matter in the first place. However, it seems to me that (c) could be understood in a different way not considered by Aurobindo: if we understand the supraphysical force as the omnipotent God Himself, then it is hard to see why it would be logically impossible for God to "infuse" life into nonliving matter from without. Of course, this weakness in Aurobindo's argument is by no means fatal. In support of Aurobindo's involution hypothesis, we could argue that even if it is logically possible for an omnipotent God to infuse life into nonliving matter, we have no good reason to believe that such a divine intervention actually took place at that point in our evolutionary past.

We are now in a position to summarize Aurobindo's rationale for revering nature. From his Integral Advaitic standpoint, life is equally present in animals, plants, and matter, though in varying degrees of manifestation, and life itself is nothing but an intermediate plane of manifestation of the Divine Cit-Śakti itself, which has gone on to manifest at the plane of mind-in present-day human beings-and will eventually manifest in its fullness as Supermind. Hence, through reverence for nature, we express our reverence for the Divine immanent in everything and thereby facilitate and accelerate the process of spiritual evolution that will culminate in a divine life here on earth.

The UN recently released a massive Climate Change report (Masson-Delmotte et al. Forthcoming), the alarming findings of which U.N. Secretary General António Guterres called "a code red for humanity". According to the report, "human-induced climate change is already affecting many weather and climate extremes in every region across the globe" (Masson-Delmotte et al. Forthcoming, p. 10). The report further notes that unless we take immediate action to make deep reductions in carbon dioxide $\left(\mathrm{CO}_{2}\right)$ and other greenhouse gas emissions, further global warming in the next century will result in catastrophic and irreversible consequences for the planet.

In our current ecological crisis, thinkers are mining global philosophical traditions for worldviews and metaphysical frameworks that might support ecological consciousness and activism. For too long, scholars of Indian thought have tended to assume that the Advaita Vedānta championed by Śankara and his followers is the most promising nondual philosophical basis for a robust environmental ethics. Fortunately, thanks in part to Aurobindo, scholars are increasingly exploring the potential of alternative, life-affirming forms of nondualism to address contemporary ecological, ${ }^{23}$ social, and philosophical problems.

Funding: This research received no external funding.

Conflicts of Interest: The author declares no conflict of interest.

\section{Notes}

1 This is at least one mainstream and highly influential interpretation of the Advaita philosophy of Gaudapāda and Śankara—an interpretation defended, for instance, by Sadananda (1931), Chatterjee and Datta (2008, pp. 365-412), Mahadevan (1957), Deutsch (1988, pp. 39-42), and Nelson (2010). Nonetheless, some scholars have argued that Śankara did not take the personal God and world to be ultimately nonexistent (De Smet 1987; Malkovsky 1997; Guha et al. 2021, pp. 63-78). It would require a different essay to address in detail the question of how Śankara's philosophy should be interpreted. For present purposes, what is important is that Aurobindo himself definitely interpreted Śankara in a nonrealist manner. At the end of Section 4, I also quote some passages from Śankara's commentaries that support Aurobindo's nonrealist interpretation. 
As Phillips (1986, pp. 175-77) has pointed out, Aurobindo is deliberately vague about precisely when this inevitable transition from Mind to Supermind will occur, in part because we can hasten or delay the process through our own actions.

3 None of the letters quoted in this section are dated, but they were all written some time between 1927 and 1950.

4 Śrutyādayah anubhavādayah ca yathāsambhavam iha pramānam anubhavāvasānatvāt bhütavastuvișayatvāt ca brahmajñānasya.

5 Rambachan (1991, pp. 113-16; 1994, pp. 721-24), by contrast, argues that what Śankara means is that anubhava, as well as other pramānas such as inference, are only valuable supplements to scripture, which is the one and only pramāna for gaining knowledge of Brahman. Meanwhile, other scholars have suggested a variety of other interpretations of this passage (Gupta 2009, pp. 267-79; Preti 2014).

6 See, for instance, Śankara's commentary on Gītā 5.26.

7 See, for instance, Swinburne (2004, pp. 293-327), Davis (1989), Gellman (1997), Alston (1991), and Kwan (2009).

8 Aurobindo uses this phrase in Essays on the Gita (CWSA 19, p. 244).

9 asthāsyad ekarūpena vapuṣā cen maheśvarah | maheśvaratvam saṃvittvam tad atyaksad ghatāadivat.

10 I explain Aurobindo's "logic of the infinite" in more detail in Maharaj (2018, pp. 119-24).

11 kasya punar ayam aprabodha iti cet. yas tvam prcchasi tasya ta iti vadāmah. nanv aham îśvara evoktah śrutyā, yadi evam pratibuddho 'si nāsti kasyacid aprabodhah.

12 Aurobindo studied, in the original Sanskrit, not only some of Śankara's commentaries but also Gaudapāda's Māndūkya-Kārikā and Sadānanda's Vedāntasāra, an extremely popular and influential post-Śankara Advaitic textbook. This is clear from the fact that at some point between 1900 and 1902, Aurobindo translated into English part of Gaudapāda's Māndū ūkya-Kārikā, along with (pseudo?)-Śañkara's commentary (CWSA 18, pp. 319-29) and part of Sadānanda's Vedāntasāra (CWSA 18, pp. 330-33).

Although Aurobindo does not explicitly refer to any post-Śankara Advaitins here or anywhere else in The Life Divine, he had read Sadānanda's Vedāntasāra (as mentioned in my previous note), which characterizes ignorance (ajñannam) as "not describable as either real or unreal" (sadasadbhyām anirvacanīyam) (Sadananda 1931, p. 23).

Of course, the Advaitin could object that Aurobindo makes the mistake of assuming that Brahman really has the "power" to "create nonexistent things". In fact, the Advaitin could argue, Brahman's power to project illusions is itself illusory, and hence, nothing exists alongside Brahman to compromise its nonduality. However, we should recall that Aurobindo's objection specifically targets the post-Śankaran Advaitic position that māya is not completely unreal but anirvacañya —-that is, neither real nor unreal. As we will soon see, Aurobindo immediately goes on to consider the radical illusionist position endorsed by some Advaitins like Gaudiapāda.

Aurobindo does not mention Gaudapāda by name anywhere in The Life Divine, but as I have already pointed out in note 12, he had read Gauḍapāda's Mānd ụ̂kya-Kārikā, so it seems likely that he had Advaitins like Gauḍapāda in mind.

16 Aurobindo was by no means the first to have made this argument. For instance, Vallabha's follower Giridhara (2000, pp. 22-23) argued that if Advaitins posit māy $\bar{a}$ as the beginningless source of this world-illusion, then the nonduality of Brahman would be compromised, since there would be a duality of Brahman and māya (Śuddhādvaitamārtandạ, verses 23-4).

Aurobindo makes a similar remark in (CWSA 29, pp. 449-50). He may have been thinking of his contemporary Sarvepalli Radhakrishnan, who sometimes interpreted Śankkara's Advaita in a more realist manner (Braue 1984).

Likewise, a bit later in The Life Divine, Aurobindo explicitly states that Śankara posits "an unreal reality" (CWSA 21-22, p. 481). na ceyam paramārthavișayā ș̣̦țiśrutih; avidyākalpitanāmarūpavyavahāragocaratvāt.

tad evam avidyātmakopādhiparicchedāpekșam eva îšvarasya îsvaratvam sarvajñatvam sarvaśaktitvam ca na paramārthato vidyayāa apāstasarvopādhisvarūpe ātmani īsitrīisitavyasarvajñatvādivyavahāra upapadyate.

In support of this claim, Aurobindo refers to the work of a "great Indian physicist" (Jagadish Chandra Bose, 1858-1937) who conducted experiments that he took to prove the existence of a nervous system in plants (CWSA 21-22, p. 197).

In contemporary evolutionary biology, the hypothesis that life arose from nonliving matter is known as "abiogenesis". While most contemporary biologists accept the occurrence of abiogenesis, they continue to debate the specific processes involved in abiogenesis. From Aurobindo's standpoint, contemporary scientists unjustifiably assume that matter is nonliving. What is indisputable is that life evolved from matter, but it remains an open question whether matter itself is nonliving or has life in some latent form.

See, for instance, Tatray (2006), Loy (1997), Coward (2003), and Framarin (2014, pp. 61-76).

\section{References}

\section{Primary Sources}

CWSA 6-7: Aurobindo, Sri. 2002. The Complete Works of Sri Aurobindo, Volumes 6-7: Bande Mataram. Pondicherry: Sri Aurobindo Ashram.

CWSA 8: Aurobindo, Sri. 1997. The Complete Works of Sri Aurobindo, Volume 8: Karmayogin: Political Writings and Speeches 1909-1910. Pondicherry: Sri Aurobindo Ashram. First published 1909-1910. 
CWSA 10-11: Aurobindo, Sri. 2001. The Complete Works of Sri Aurobindo, Volumes 10-11: Record of Yoga. Pondicherry: Sri Aurobindo Ashram.

CWSA 13: Aurobindo, Sri. 1998. The Complete Works of Sri Aurobindo, Volume 13: Essays in Philosophy and Yoga: Shorter Works 1910-1950. Pondicherry: Sri Aurobindo Ashram. First published 1909-1950.

CWSA 15: Aurobindo, Sri. 1998. The Complete Works of Sri Aurobindo, Volume 15: The Secret of the Veda. Pondicherry: Sri Aurobindo Ashram. First published 1914-1916.

CWSA 17: Aurobindo, Sri. 2011. The Complete Works of Sri Aurobindo, Volume 17: The Upanishads-I: Isha Upanishad. Pondicherry: Sri Aurobindo Ashram. First published 1924.

CWSA 18: Aurobindo, Sri. 2001. The Complete Works of Sri Aurobindo, Volume 18: Kena and Other Upanishads. Pondicherry: Sri Aurobindo Ashram. First published 1900-1914.

CWSA 19: Aurobindo, Sri. 1997. The Complete Works of Sri Aurobindo, Volume 19: Essays on the Gita. Pondicherry: Sri Aurobindo Ashram. First published 1922-1928.

CWSA 21-22: Aurobindo, Sri. 2005. The Complete Works of Sri Aurobindo, Volumes 21-22: The Life Divine. Pondicherry: Sri Aurobindo Ashram.

CWSA 29: Aurobindo, Sri. 2013. The Complete Works of Sri Aurobindo, Volume 29: Letters on Yoga II. Pondicherry: Sri Aurobindo Ashram.

CWSA 35: Aurobindo, Sri. 2011. The Complete Works of Sri Aurobindo, Volume 35: Letters on Himself and the Ashram. Pondicherry: Sri Aurobindo Ashram. First published 1926-1950.

CWSA 36: Aurobindo, Sri. The Complete Works of Sri Aurobindo, Volume 36: Autobiographical Notes and Other Writings of Historical Interest. Pondicherry: Sri Aurobindo Ashram.

\section{Secondary Sources}

Albahari, Miri. 2019a. Beyond Cosmopsychism and the Great I Am: How the World Might Be Grounded in Advaitic Universal Consciousness. In Routledge Handbook of Panpsychism. Edited by William Seager. London: Routledge, pp. 119-30.

Albahari, Miri. 2019b. Perennial Idealism: A Mystical Solution to the Mind-Body Problem. Philosophers' Imprint 19 : 1-37.

Alston, William. 1991. Perceiving God: The Epistemology of Religious Experience. Ithaca: Cornell University Press.

Bhushan, Nalini, and Jay L. Garfield. 2017. Minds Without Fear: Philosophy in the Indian Renaissance. New York: Oxford University Press.

Braue, Donald A. 1984. Māyā in Radhakrishnan's Thought: Six Meanings Other Than Illusion. Delhi: Motilal Banarsidass.

Chalmers, David. 1995. Facing Up to the Problem of Consciousness. Journal of Consciousness Studies 2: 200-19.

Chatterjee, Satischandra, and Dhirendramohan Datta. 2008. An Introduction to Indian Philosophy. Calcutta: University of Calcutta.

Comans, Michael. 1993. The Question of the Importance of Samādhi in Modern and Classical Advaita Vedānta. Philosophy East and West 43: 19-38. [CrossRef]

Coward, Harold. 2003. Hindu Views of Nature and the Environment. In Nature Across Cultures: Views of Nature and the Environment in Non-Western Cultures. Edited by Helaine Selin and Arne Kalland. Dordrecht: Springer, pp. 411-20.

Davis, Caroline Franks. 1989. The Evidential Force of Religious Experience. Oxford: Clarendon Press.

De Smet, Richard. 1987. Forward Steps in Sankara Research. Darshana International 26: 33-46.

Deutsch, Eliot. 1970. Vedānta and Ecology. Indian Philosophical Annual 7: 79-88.

Deutsch, Eliot. 1988. Advaita Vedānta: A Philosophical Reconstruction. Honolulu: University of Hawaii Press.

Deutsch, Eliot. 1989. A Metaphysical Grounding for Natural Reverence: East-West. In Nature in Asian Traditions of Thought. Edited by J. Baird Callicott and Roger T. Ames. Albany: State University of New York Press, pp. 259-65.

Devaraja, Nand Kishore. 1962. An Introduction to Śañkara's Theory of Knowledge. Delhi: Motilal Banarsidass.

Framarin, Christopher. 2014. Hinduism and Environmental Ethics: Law, Literature, and Philosophy. London: Routledge.

Gasparri, Luca. 2019. Priority Cosmopsychism and the Advaita Vedānta. Philosophy East and West 69: 130-42. [CrossRef]

Gellman, Jerome. 1997. Experience of God and the Rationality of Theistic Belief. Ithaca: Cornell University Press.

Giridhara. 2000. Śuddhādvaitamārtandah. Edited by Ratna Gopal Bhatta. Varanasi: Chowkhamba.

Grimes, John. 1990. The Seven Great Untenables (Sapta-Vidhä Anupapatti). Delhi: Motilal Banarsidass.

Guha, Nirmalya, Matthew R. Dasti, and Stephen H. Phillips. 2021. God and the World's Arrangement. Indianapolis: Hackett.

Gupta, Bina. 2009. Reason and Experience in Indian Philosophy. Delhi: Indian Council of Philosophical Research.

Gupta, Lina. 1994. Ganga: Purity, Pollution, and Hinduism. In Ecofeminism and the Sacred. Edited by Carol J. Adams. New York: Continuum, pp. 99-116.

Gupta, Mahendranath. 1992. The Gospel of Sri Ramakrishna. Translated by Swami Nikhilananda. New York: Ramakrishna-Vivekananda Center. First published 1942.

Gupta, Mahendranāth. 2010. Śrīśrīrāmakṛṣnakathāmṛta: Śrīma-Kathita. Kolkata: Udbodhan. First published 1897-1932.

Hacker, Paul. 1995. Philology and Confrontation: Paul Hacker on Traditional and Modern Vedānta. Edited by Wilhelm Halbfass. Albany: SUNY Press.

Ingalls, Daniel. 1953. Śankara on the Question: Whose is Avidyā? Philosophy East and West 3: 69-72. [CrossRef]

Kwan, Kai-Man. 2009. The Argument from Religious Experience. In The Blackwell Companion to Natural Theology. Edited by William Lane Craig and James Porter Moreland. New York: Blackwell, pp. 498-552.

Lidke, Jeffrey S. 2017. The Goddess Within and Beyond the Three Cities: Śäkta Tantra and the Paradox of Power in Nepāla-Mandala. Delhi: D.K. Printworld. 
Loy, David R. 1997. Loving the World as Our Own Body: The Nondualist Ethics of Taoism, Buddhism and Deep Ecology. Worldviews 1: 249-73. [CrossRef]

Madhavananda, Swami, trans. 1921. Vivekacūdāmani. Mayavati: Advaita Ashrama.

Mahadevan, Telliyavaram Mahadevan Ponnambalam. 1957. The Philosophy of Advaita. Madras: Ganesh \& Co.

Maharaj, Ayon. 2015. Toward a New Hermeneutics of the Bhagavad Gïtā: Sri Ramakrishna, Sri Aurobindo, and the Secret of Vijñ̄ana. Philosophy East and West 65: 1209-1233. [CrossRef]

Maharaj, Ayon. 2018. Infinite Paths to Infinite Reality: Sri Ramakrishna and Cross-Cultural Philosophy of Religion. New York: Oxford University Press.

Maharaj, Ayon. 2020a. Seeing Oneness Everywhere: Sri Aurobindo's Mystico-Immanent Interpretation of the Ísaa Upanișad. In The Bloomsbury Research Handbook of Vedānta. Edited by Ayon Maharaj. London: Bloomsbury, pp. 309-40.

Maharaj, Ayon. 2020b. Śiva Jñāne Jìver Sevā: Reexamining Swami Vivekananda's Practical Vedānta in the Light of Sri Ramakrishna. Journal of Dharma Studies 2: 175-87. [CrossRef]

Malkovsky, Bradley. 1997. The Personhood of Śankara's Para Brahman. Journal of Religion 77: 541-62. [CrossRef]

Masson-Delmotte, V., P. Zhai, A. Pirani, S. L. Connors, C. Péan, S. Berger, N. Caud, Y. Chen, L. Goldfarb, M. I. Gomis, and et al., eds. Forthcoming. Climate Change 2021: The Physical Science Basis. Contribution of Working Group I to the Sixth Assessment Report of the Intergovernmental Panel on Climate Change. Cambridge: Cambridge University Press.

Medhananda, Swami. 2021. Why Sri Aurobindo's Hermeneutics Still Matters: Philology and the Transformative Possibilities of Scripture. Religions 12: 484. [CrossRef]

Medhananda, Swami. Forthcoming a. Swami Vivekananda's Vedāntic Cosmopolitanism. New York: Oxford University Press.

Medhananda, Swami. Forthcoming b. The Playful Self-Involution of Divine Consciousness: Sri Aurobindo's Evolutionary Cosmopsychism and His Response to the Individuation Problem. The Monist.

Murty, K. Satchidananda. 1959. Revelation and Reason in Advaita Vedānta. Bombay: Asia Publishing House.

Nelson, Lance. 2010. The Dualism of Nondualism: Advaita Vedānta and the Irrelevance of Nature. In Purifying the Earthly Body of God: Religion and Ecology in India. Edited by Lance Nelson. Albany: SUNY Press, pp. 61-88.

Narain, Kailash. 2004. The Philosophy of the Vällabha School of Vedānta. Varanasi: Indological Research Centre.

Nemec, John. 2011. The Ubiquitous Śiva: Somānanda's Śivadṛști and His Tantric Interlocutors. New York: Oxford University Press.

Padiyath, Thomas. 2014. The Metaphysics of Becoming: On the Relationship Between Creativity and God in Whitehead and Supermind and Sachchidananda in Aurobindo. Berlin: Walter de Gruyter.

Phillips, Stephen H. 1986. Aurobindo's Philosophy of Brahman. Leiden: E.J. Brill.

Phillips, Stephen H. 2001. Could There Be Mystical Evidence for a Nondual Brahman? A Causal Objection. Philosophy East and West 51: 492-506. [CrossRef]

Preti, Alan A. 2014. Brahmānubhava as Überpramāna in Advaita Vedānta: Revisiting an Old Debate. Philosophy East and West 64: 718-39. [CrossRef]

Prince, Brainerd. 2017. The Integral Philosophy of Aurobindo: Hermeneutics and the Study of Religion. London: Routledge.

Rambachan, Anantanand. 1989. The Value of the World as the Mystery of God in Advaita Vedānta. Journal of Dharma 14: $287-97$.

Rambachan, Anantanand. 1991. Accomplishing the Accomplished: The Vedas as a Source of Valid Knowledge in Śankara. Honolulu: University of Hawaii Press.

Rambachan, Anantanand. 1994. The Limits of Scripture: Vivekananda's Reinterpretation of the Vedas. Honolulu: University of Hawaii Press.

Ratié, Isabelle. 2017. An Indian Debate on Optical Reflections and Its Metaphysical Implications: Śaiva Nondualism and the Mirror of Consciousness. In Indian Epistemology and Metaphysics. Edited by Joerg Tuske. London: Bloomsbury, pp. $207-40$.

Sadananda, Swami. 1931. Vedāntasāra. Translated by Swami Nikhilananda. Mayavati: Advaita Ashrama.

Sharma, Arvind. 1992. Is Anubhava a Pramāna According to Śankkara? Philosophy East and West 42: 517-26. [CrossRef]

Sherma, Rita DasGupta. 2010. Sacred Immanence: Reflections of Ecofeminism in Hindu Tantra. In Purifying the Earthly Body of God: Religion and Ecology in India. Edited by Lance Nelson. Albany: SUNY Press, pp. 89-132.

Singh, Jaideva. 1980. Pratyabhijñāhṛdayam: The Secret of Self-Recognition. Delhi: Motilal Banarsidass.

Singh, Jaideva. 1985. Vedānta and Advaita Śaivāgama of Kashmir: A Comparative Study. Calcutta: Ramakrishna Mission Institute of Culture.

Smith, Frederick M. 2011. Predestination and Hierarchy: Vallabhācārya's Discourse on the Distinctions Between Blessed, Rule-Bound, Worldly, and Wayward Souls (the Puștipravāhamaryādābheda). Journal of Indian Philosophy 39: 173-227. [CrossRef]

Swinburne, Richard. 2004. The Existence of God, 2nd ed. Oxford: Clarendon Press.

Tatray, Dara. 2006. Rebuilding the Foundations of Deep Ecology: A Nondualist Approach. Ph.D. dissertation, University of New South Wales, Sydney, Australia.

Vaidya, Anand. 2020. A New Debate on Consciousness: Bringing Classical and Modern Vedānta into Dialogue with Contemporary Analytic Panpsychism. In The Bloomsbury Research Handbook of Vedānta. Edited by Ayon Maharaj. London: Bloomsbury. 